\title{
THE SYNTAX AND SEMANTICS INTERFACE OF PRESENT-DAY AND OLD ENGLISH SPEECH VERBS: SAY AND TELL VERSUS SECGAN AND TELLAN
}

\author{
MarTA M. ${ }^{a}$ GonZÁlez OrTA \\ Universidad de La Laguna
}

\begin{abstract}
The aim of this paper is to analyse the syntax-semantics interface of the Old English speech verbs secgan and tellan, and the Present-day English speech verbs say and tell, respectively, in order to show the differences in each language when linking their syntactic and semantic representations. In this analysis the concept of lexical template has been applied as a lexical representation which includes syntactic and semantic information within the same format and allows us to capture linguistic regularities. Moreover, taking into account the syntactic alternations of these verbs a comparison between them will be established in terms of the degree of semantic prototypicality that they show within their respective domains and with respect to their transitivity.
\end{abstract}

\section{INTRODUCTION: THE FUNCTIONAL-LEXEMATIC MODEL}

The aim of this paper is to analyse the syntax-semantics interface of the Old English (OE) speech verbs secgan and tellan, and the Present-day English (PDE) speech verbs say and tell, in order to show the differences in their syntactic behaviour. These differences will be the result of applying the lexical rules which provide the linking algorithm between the syntactic and semantic representations in each language. In order to capture the syntaxsemantics interface, lexical templates have been integrated within the functional-lexematic approach.

The Functional-Lexematic Model (FLM), developed by Martín Mingorance (1998) and inspired by the principle of Stepwise Lexical Decomposition (Dik 1978), is devised for the purpose of supplying the Functional Grammar (FG) lexicon with the onomasiological classification of lexemes within domains and 
subdomains, as a way of reflecting the organisation of our mental lexicon and demonstrating the close relationship between syntax and semantics (Martín Mingorance 1998; Faber and Mairal Usón 1994, 1997a, 1997b, 1999).

According to the paradigmatic axis of the FLM based on the principles of Lexematics (Coseriu 1978, 1981), the criteria to integrate a given lexeme in a (sub-)domain are based on its lexical decomposition, in such a way that the definition of the lexeme must contain a nuclear word or genus, shared by the group of lexemes that integrate that (sub-)domain, and a set of differentiating features or differentiae specificae, which establish functional oppositions between the lexemes of the (sub-)domain. Faber and Mairal Usón (1999: 87) propose the Principle of Lexical Domain Membership, which says, "lexical domain membership is determined by the genus, which constitutes the nucleus of the meaning of a lexeme".

The hierarchical organisation of the lexicon within (sub-)domains allows linguistic regularities to be captured, such as the repetition of similar complementation patterns for the lexical units within the same (sub-)domain, due to the fact that the syntactic behaviour of predicates seems to be motivated by the (sub-)domain in which they are integrated (cf. section 3).

\section{THE CONCEPT OF LEXICAL TEMPLATE WITHIN THE FUNCTIONAL- LEXEMATIC MODEL}

The syntagmatic axis of the FLM was initially based on the FG notion of predicate frame, together with the contributions made to the analysis of verbal complementation by Mairal Usón (1993) and Faber and Mairal Usón (1999). Nevertheless, Cortés Rodríguez and Mairal Usón (forthcoming), Cortés Rodríguez and Pérez Quintero (2001), Faber and Mairal Usón (2000), and Mairal Usón and Van Valin (2001) have brought to light the inadequacy of predicate frames to reflect the interaction between the semantic and syntactic behaviour of predicates.

In FG, each lexical entry is represented in the lexicon in the form of a predicate frame, which provides the combinatory possibilities for a predicate. In addition, each lexical entry is associated with a meaning definition following the postulates of Stepwise Lexical Decomposition. Nevertheless, a crucial weakness of this representational system is that there is no explanation on how the syntactic behaviour and the semantic representation of predicates interact.

Accordingly, the authors mentioned above suggest the enrichment of FG predicate frames by applying Role and Reference Grammar (RRG) logical structures along with the notion of semantic macroroles instead of the FG inventory of semantic functions, the result being a procedure of lexical representation where meaning description is encapsulated and interacts with 
the syntactic behaviour of lexical units. These contributions will become the basis of lexical templates.

Lexical templates are designed as a way of including semantic and syntactic information within the same format, reflecting generalisations across lexical classes and reducing the information to be included in lexical entries. Moreover, given the fact that (sub-)domains are considered repositories of linguistic regularities, they propose that each (sub-)domain will be characterised by a lexical template from which syntactic alternations will be predicted.

In order to construct a lexical template, the logical structures developed by Van Valin and LaPolla (1997) will be complemented by the semantic component of the FLM, since logical structures lack the semantic information characteristic of the different lexical (sub-)domains. Accordingly, Faber and Mairal Usón (2000: 7) describe lexical templates in the following way: Lexical templates conflate both syntactic information (those aspects of the meaning of a word which are grammatically relevant) and semantic information (those aspects which act as distinctive parameters within a whole lexical class) into one unified representation.

Within RRG, four classes of verbal predicates are distinguished: states [+static] [-telic] [-punctual], activities [-static] [-telic] [-punctual], achievements [-static] [+telic] [+punctual], and accomplishments (and active accomplishments) [-static] [+telic] [-punctual], together with their causative counterparts. This classification of verbal predicates attending to their Aktionsart will allow for the capture of syntactic phenomena, such as the combinatory possibilities of predicates, and morphological phenomena, such as transitivity and case assignment, characteristic of the different verbal classes.

These are the lexical representations corresponding to the verbal classes mentioned above (Van Valin and LaPolla 1997: 109):

\begin{tabular}{|c|c|}
\hline Verb class & Logical structure \\
\hline State & predicate' $(\mathrm{x})$ or $(\mathrm{x}, \mathrm{y})$ \\
\hline Activity & do' $(\mathrm{x}$, [predicate' $(\mathrm{x})$ or $(\mathrm{x}, \mathrm{y})])$ \\
\hline Achievement & $\begin{array}{l}\text { INGR predicate' }(\mathrm{x}) \text { or }(\mathrm{x}, \mathrm{y}) \text {, or } \\
\text { INGR do' }(\mathrm{x},[\text { predicate' }(\mathrm{x}) \text { or }(\mathrm{x}, \mathrm{y})])\end{array}$ \\
\hline Accomplishment & $\begin{array}{l}\text { BECOME predicate' }(\mathrm{x}) \text { or }(\mathrm{x}, \mathrm{y}) \text {, or } \\
\text { BECOME do' }(\mathrm{x}, \text { [predicate' }(\mathrm{x}) \text { or }(\mathrm{x}, \mathrm{y})])\end{array}$ \\
\hline Active accomplishment & $\begin{array}{l}\left.\text { do' }^{\prime} \mathrm{x},\left[\text { predicate }_{1}^{\prime}(\mathrm{x},(\mathrm{y}))\right]\right) \text { \& BECOME } \\
\text { predicate }_{2}(\mathrm{z}, \mathrm{x}) \text { or }(\mathrm{y})\end{array}$ \\
\hline Causative & $\alpha$ CAUSES $\beta$ where $\alpha, \beta$ are LS of any type \\
\hline
\end{tabular}

Table 1. Lexical representations for Aktionsart classes 
In order to attain the argument structure of a verb, it is necessary to determine firstly its Aktionsart, from which its logical structure will be created and along with it its argument structure. Van Valin and LaPolla (1997: 139) propose two general semantic relations, the Actor (A) and Undergoer (U) macroroles, which are generalizations across the argument-types found with particular verbs which have significant grammatical consequences. Thus, as Figure 1 shows, the Actor macrorole comprises those arguments whose nature is closer to that of an Agent and the Undergoer subsumes those arguments closer to a Patient:

ACTOR

Arg. of

DO

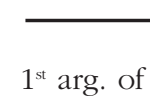

$$
\text { do' }(\mathrm{x}, \ldots
$$

\section{[' $\rightarrow$ ' = increasing markedness of realization of argument as macrorole]}

Figure 1. The Actor-Undergoer Hierarchy

Macroroles will be assigned to core arguments, that is, those arguments with no morphological marking (PDE) or marked by the grammatical case (OE), and not to oblique arguments, which are marked by a preposition. With respect to the criteria that determine the interaction between arguments and macroroles, these authors propose the following Default Macrorole Assignment Principles (1997: 152-153):

a. Number: the number of macroroles a verb takes is less than or equal to the number of arguments in its logical structure,

1. If a verb has two or more arguments in its LS, it will take two macroroles.

2. If a verb has one argument in its LS, it will take one macrorole.

b. Nature: for verbs which take one macrorole,

2. If the verb has an activity predicate in its LS, the macrorole is actor.

3. If the verb has no activity predicate in its LS, the macrorole is undergoer.

In RRG, transitivity becomes a semantic notion since the number of semantic macroroles a predicate takes determines it: those verbs that take one macrorole are intransitive verbs, whereas those with two macroroles are transitive. Verbs which do not take any macrorole are considered atransitive. Moreover, Case assignment rules (for accusative languages) are also related to the assignment of macroroles (1997: 359):

a. Assign nominative case to the highest-ranking macrorole argument.

b. Assign accusative case to the other macrorole argument.

c. Assign dative case to non-macrorole arguments (default). 
Therefore, taking into account the Default Macrorole Assignment Principles and the Actor-Undergoer Hierarchy, the information to be included in the lexical representations will be reduced. Firstly, syntactic information is derived from the semantic notion of transitivity being based on the Default Macrorole Assignment Principles. Secondly, it is not necessary to specify the macroroles assigned to the arguments of the verbs since the Actor-Undergoer Hierarchy provides this information.

\section{THE SYNTAX-SEMANTICS INTERFACE OF SAY/SECGAN AND TELL/TELLAN}

In this section the analysis of the syntax-semantics interface of the speech verbs say/secgan and tell/tellan will be compared in order to show the differences in their syntactic and semantic behaviour. In order to obtain the syntactic contexts in which these lexemes appear, the OE verbs secgan and tellan will be located in The Dictionary of Old English Corpus ${ }^{1}$ and the results will be compared with the information in Bosworth and Toller (1973) and Toller and Campbell (1972). For the PDE verbs say and tell, the syntactic alternations included in Levin (1993) and Mairal Usón (1993) will be considered.

Following Van Valin and LaPolla (1997: 116-118), the template corresponding to say/secgan is presented below:

do' $\left(x\right.$, [express. $\left.\left.(\alpha) . t o .(\beta) . i n . l a n g u a g e .(\gamma)^{\prime}(x, y)\right]\right) \&$ [BECOME aware.of' $\left.(y, z)\right]$, where $y=\beta, z=\alpha$

This template contains the logical structure of an accomplishment, where a speaker $(\mathrm{x})$ says something $(\alpha)$ to a hearer $(\beta)$ and then the latter becomes aware of it. It shows three internal variables $\alpha, \beta, \gamma$ (marked by Greek letters) making reference to the content of the expression, to the addressee and to the language used, respectively, and three external variables $\mathrm{x}, \mathrm{z}, \mathrm{y}$, where $\mathrm{x}$ will make reference to the speaker, $\mathrm{z}$ to $\alpha$ or the content of the expression, and $\mathrm{y}$ to $\beta$ or the hearer.

Internal variables differ from external variables because the latter correspond to external argument positions with a syntactic representation, whereas the former belong to the semantic representation of speech verbs,

1. The Dictionary of Old English electronic corpus is a complete record of surviving OE except for some variant manuscripts of individual texts. There are 3037 text in the corpus including poetry, prose, interlinear glosses, glossaries, runic inscriptions and inscriptions in the Latin alphabet. 
that is, they function as ontological constants of this verbal class and their introduction will allow for the addition of a semantic decomposition to the logical structure giving rise to the lexical template for this lexical domain.

Within the speech domain the alternation activity-accomplishment can take place, depending on the context in which these verbs appear. The semantic feature differentiating their Aktionsart is the telicity of the latter, which will activate a transitive structure, in opposition to the intransitive use of activity verbs. Therefore, syntactic alternations will correlate with different realisations of internal variables as external ones. The logical structure corresponding to speech activity verbs is presented below:

do' $\left(x,\left[\right.\right.$ express. $(\alpha)$. to. $(\beta)$. in.language. $\left.\left.(\gamma)^{\prime}(x, y)\right]\right)$

Faber and Mairal Usón (2000: 28) suggest the process that governs the mapping between a lexical template and the different syntactic structures within a lexical class. The Lexical Template Modeling Process says that "lexical templates can be modeled by suppressing external variables, instantiating internal variables, eliminating operators (e.g. CAUSE), or else, by introducing elements resulting from the fusion with other templates". Thus, "all of the alternations involve reductions from the maximal LS underlying the class". In this case, the maximal lexical template for say/secgan corresponds to an accomplishment and from this one, following a reduction process, the alternation activity will be derived.

The lexical template corresponding to tell/tellan contains the logical structure of a causative accomplishment where a speaker $(\mathrm{x})$ says something $(\alpha)$ to a hearer $(\beta)$ causing him to become aware of it. It also shows three internal variables $\alpha, \beta, \gamma$ and three external variables $\mathrm{x}, \mathrm{z}, \mathrm{y}$, where $\mathrm{x}$ will make reference to the speaker, $\mathrm{z}$ to $\alpha$ or the content of the expression, and $\mathrm{y}$ to $\beta$ or the hearer:

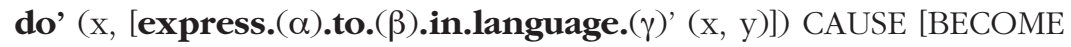

Applying the Lexical Template Modeling Process, the maximal template for tell/tellan corresponds to a causative accomplishment and from this one the alternation activity can be derived. As section 2 shows, logical structures are universal but the lexical rules that provide the linking algorithm between the syntactic and semantic representation of these verbs can differ in each language. Therefore, say/secgan and tell/tellan share the same logical structure, accomplishment in the case of say/secgan and causative accomplishment in the case of tell/tellan, but there are some differences when linking their syntactic and semantic representations, as it will be explained below. 


\subsection{SYNTACTIC BEHAVIOUR OF SAY/SECGAN}

(1) do' (x, [express. $(\alpha)$.to. $(\beta)$.in.language. $\left.\left.(\gamma)^{\prime}(\mathrm{x}, \mathrm{y})\right]\right)$ \& [BECOME aware.of' $(y, z)]$, where $y=\beta, z=\alpha$

1.1 Say: $\mathrm{x}$ (A), z [Sentential coordination], y (oblique core arg)

She kept saying to me, "Don't forget, will you?"

Secgan: $\mathrm{x}$ (Nom-A), z [Sentential coordination], y (oblique core arg) and bu mibt zu secgan to dinum breдer дus: geдafa, min brodor, doet ic doet mot ateo of dinum eagan nu

"And how you might say to your brother thus: "Admit, my brother, that I remove now that mote of this eye"

1.2 Say: $\mathrm{x}$ (A), z [Core coordination], y (oblique core arg)

She said for me to leave early.

Secgan:

1.3 Say: $x$ (A), z [Clausal subordination-U], y (oblique core argument)

Ellen said to Helen that melons were selling well.

Secgan: $x$ (Nom-A), z [Clausal subordination-U], y (Dat)

ne mihte he (...) him openlice secgan doet his eawfæeste wif on dœre wodnysse log

'He might not say to him openly that his wife fell in madness'

1.4 Say:

Secgan: $\mathrm{x}$ (Nom-A), z [Clausal subordination-U], y (Dat)

ac we wyllad eow secgan nu orest hu he com to dœere byrig hierusalem

'But we will say to you now how he came to Jerusalem'

1.5 Say: x (A), z (U), y (oblique core argument)

Ellen said something/a few words to Helen.

Secgan: $x$ (Nom-A), z (Acc-U), y (Dat)

Se mœessepreost sceal secgan sunnandagum and mœssedagum does godspelles angyt on englisc dam folce

'The masspriest will say to people on Sundays and massdays the meaning of the gospel in English'

(2) do' $\left(x,\left[\right.\right.$ express. $(\alpha)$.to. $(\beta)$.in.language. $\left.\left.(\gamma)^{\prime}(x, \varnothing)\right]\right)$ \& [BECOME aware.of' $(\varnothing, z)]$, where $\varnothing=\beta, z=\alpha$ 
2.1. Say: $x$ (A), z [Sentential coordination]

"Please, come in," she said.

Secgan: $x$ (Nom-A), z [Sentential coordination]

Apollonius søede: Fordam de ic boed his dohtor me to gemøeccan "Apollonius said: "Therefore I commanded his daughter to cohabit with me"”

2.2 Say: $x(A), z$ [Core coordination]

She said to meet here at the station.

Secgan:

2.3. Say: $x$ (A), z [Clausal subordination-U]

Ellen said that the melons were selling well.

Secgan: $x$ (Nom-A), z [Clausal subordination-U]

swa we œr gehyrdon secgan dœet se eadiga Simeon wœs sodfœest \& cloene \& godfyrht on his life

'So we heard to say that the blessed Simeon was honest and clean and godfearing in his life'

2.4. Say: x (A), z [Clausal subordination-U]

Did she say how she got here?

Secgan: $x$ (Nom-A), z [Clausal subordination-U]

Ic wylle secgan, hwoet hi ealle habbad 'I will say what they all have'

2.5 Say: $x(A), z(\mathbf{U})$

I didn't say anything.

Secgan: $x$ (Nom-A), z (Acc-U)

Hyrde ic secgan (...) doet word 'I heard to say that word'

(3) do' $\left(x\right.$, [express. $\left.\left.(\alpha) . t o .(\beta) . i n . l a n g u a g e .(\gamma)^{\prime}(x, y)\right]\right) \wedge\left[\right.$ about' $\left.^{\prime}(z)\right]$, where $\alpha=$ [about'(z)]

Say:

Secgan: $x($ Nom-A), [be/embe + Dat PP], y (Dat)

Gyt we wyllad eow secgan be sumon gesoligon cyninge

'Yet we will talk to you about some prosperous king'

(4) do' $\left(x,\left[\right.\right.$ express. $\left.\left.(\alpha) . t o .(\beta) . i n . l a n g u a g e .(\gamma)^{\prime}(x, \varnothing)\right]\right) \wedge[$ about' $(y)]$, where $\alpha=\left[\right.$ about' $\left.^{\prime}(y)\right]$

Say: * Ellen said about the present conditions.

Secgan: $x$ (Nom-A), [be/embe/fram + Dat PP]

da ongan se Holynd secgan be Iohanne

'Then God began to talk about John' 
(5) do' $\left(x\right.$, [express. $(\alpha)$.to. $\left.\left.(\beta) . i n . l a n g u a g e .(\gamma)^{\prime}(x, y)\right]\right)$

Say: *Ellen said to Helen.

Secgan: $x$ (Nom-A), y (Dat)

ac we wyllad eow secgan 'But we will talk to you'

(6) do' $\left(x\right.$, [express. $(\alpha)$. to. $(\beta)$.in.language. $\left.\left.(\gamma)^{\prime}(x, \varnothing)\right]\right)$

\author{
Say: \\ Secgan: $x$ (Nom-A) \\ swa se Holend søede or his drowunge \\ 'Such as God said before his passion'
}

Say and secgan are considered accomplishments where the three external variables $\mathrm{x}, \mathrm{y}, \mathrm{z}$ can be syntactically realised (1), or where only the external variables $x$ and $z$ have a syntactic realisation (2). According to the Default Macrorole Assignment Principles and the Case assignment rules, the variable $\mathrm{x}$ takes the macrorole Actor and in OE Nominative case, the variable $\mathrm{z}$ takes the macrorole Undergoer and in OE Accusative case, except when this variable is realised by a sentential coordination, a core coordination or a clausal subordination $^{2}$, and the variable $y$ when linked to $\beta$ corresponds to a non-macrorole direct core argument, which in $\mathrm{OE}$ is assigned Dative case.

Applying the Lexical Template Modeling Process, activities can be derived from the accomplishment template. Activities, which only occur with secgan, are described as follows:

- activities where one of the arguments is realised by a prepositional phrase $(3,4)$ : the variable $\mathrm{x}$ is the Actor and takes Nominative case and the variable $y$ when linked to $\beta$ is assigned Dative case

- activities where $\mathrm{x}$ and $\mathrm{y}$ are syntactically realised (5): $\mathrm{x}$ is the Actor and takes Nominative case and the variable y takes Dative case

- activities where only $\mathrm{x}$ has a syntactic realisation (6): $\mathrm{x}$ is the Actor and takes Nominative case

2. For a detailed description of complex structures, see Van Valin and LaPolla (1997: Chapter 8). According to these authors, the difference between subordinate and nonsubordinate junctures lies in the fact that only the former function as arguments of the main verb, since they may be clefted and occur as privileged syntactic arguments in a passive construction, taking therefore the macrorole Undergoer (1997: 461-462). 


\subsection{SYNTACTIC BEHAVIOUR OF TELL/TELLAN}

(1) do' $\left(x\right.$, [express. $\left.\left.(\alpha) . t o .(\beta) . i n . l a n g u a g e .(\gamma)^{\prime}(x, y)\right]\right)$ CAUSE [BECOME aware.of' $(y, z)]$, where $y=\beta, z=\alpha$

1.1 Tell: $\mathrm{x}$ (A), z [Sentential coordination], y (U)

Ellen told me, "Leave the room".

*Ellen told to me, "Leave the room".

Tellan:

1.2 Tell: $\mathrm{x}(\mathrm{A}), \mathrm{z}$ [Clausal subordination], y (U)

Ellen told Helen that the party would be tonight.

*Ellen told to Helen that the party would be tonight.

\section{Tellan:}

1.3 Tell: $\mathrm{x}$ (A), z [Clausal subordination], y (U)

Ellen told Helen how to avoid the crowd.

*Ellen told to Helen how to avoid the crowd.

Tellan: $x$ (Nom-A), z [Clausal subordination-U], y (Dat)

doet heo odrum telle oet ham, hwoet heo butan mynstre geseah odde gehyrde

'That she tells to others at home what she saw or heard outside the monastery'

1.4 Tell: $\mathrm{x}(\mathrm{A}), \mathrm{z}$ [Core coordination], y (U)

Ellen told Helen to come.

*Ellen told to Helen to come.

\section{Tellan:}

1.5 Tell: $\mathrm{x}(\mathrm{A}), \mathrm{z}(\mathbf{U}), \mathrm{y}$ (oblique core argument) Dative alternation Ellen told a story to Helen

$\mathrm{x}$ (A), z (non-MR direct core argument), y (U)

Ellen told Helen a story

Tellan: $\mathrm{x}$ (Nom-A), z (Acc-U), y (Dat)

tealdon him $\partial \mathrm{a}$ drowunga 'They told him the sufferings'

(2) do' $\left(x\right.$, [express. $(\alpha) . t o .(\beta)$.in.language. $\left.\left.(\gamma)^{\prime}(x, \varnothing)\right]\right)$

CAUSE [BECOME aware.of $(\varnothing, \mathrm{z})]$, where $\varnothing=\beta, \mathrm{z}=\alpha$

2.1. Tell: $\mathrm{x}$ (A), z [Clausal subordination-U]

*Ellen told that the party would be tonight.

You can tell he's joking. (CC) 
Tellan: $\mathrm{x}$ (Nom-A), z [Clausal subordination-U]

ah hie tealdon doette Israhela rice sceolde da sona ofter Cristes drowunga beon her on eordan mycel \& lang \& gebletsod weordan

'But they said that Israel reign should be soon after Christ's passion here on earth great and long and become blessed'

2.2. Tell: $\mathrm{x}(\mathrm{A}), \mathrm{z}$ [Clausal subordination-U]

*Ellen told how to avoid the crowd.

It was already impossible to tell where the bullet had entered. (CC)

Tellan: $\mathrm{x}$ (Nom-A), z [Clausal subordination-U]

hi tealdon hu heom gelumpon woes 'They said how it happened to them'

2.3. Tell: *Ellen told to come.

Tellan:

2.4. Tell: $\mathrm{x}(\mathrm{A}), \mathrm{z}(\mathbf{U})$

Ellen told a story.

Tellan: $x$ (Nom-A), z (Acc-U),

tealde his godan doeda swilce god hi nyste

'He told his good deeds as if God didn't know them'

(3) do' $\left(x\right.$, express. $(\alpha) . t o .(\beta)$.in.language. $\left.\left.(\gamma)^{\prime}(x, y)\right]\right)$

CAUSE [BECOME aware.of' $(y, \varnothing)$ ], where $y=\beta, \varnothing=\alpha$

Tell: $\mathrm{x}(\mathrm{A}), \mathrm{y}(\mathbf{U})$

Ellen told Helen. (elliptical)

*Ellen told to Helen.

Tellan: $x$ (Nom-A), y (Acc-U)

fordon du tellest hine 'Because you tell him'

(4) do' $\left(x\right.$, [express. $\left.\left.(\alpha) . t o .(\beta) . i n . l a n g u a g e .(\gamma)^{\prime}(x, y)\right]\right) \wedge[$ about' $(z)]$, where $\alpha=$ [about'(z)]

Tell: $\mathrm{x}$ (A), y (non-MR direct core argument), [about (z)]

Ellen told Helen about the situation.

Tellan: $x$ (Nom-A), [be + Dat PP], y (Dat)

Se ealdorman (...) tealde him be endebyrdnysse 'The ruler told them about the rule' 
(5) do' $\left(x,\left[\right.\right.$ express. $\left.\left.(\alpha) . t o .(\beta) . i n . l a n g u a g e . ~(\gamma)^{\prime}(x, \varnothing)\right]\right) \wedge[$ about' $(y)]$, where $\alpha=[$ about'(y)]

\section{Tell:}

Tellan: $\mathrm{x}$ (Nom-A), [fram + Dat PP]

deah $\partial \mathrm{u}$ nu telle from dises middangeardes fruman

'However now you talk about the beginning of this world'

(6) do' $\left(x,\left[\right.\right.$ express. $\left.\left.(\alpha) . t o .(\beta) . i n . l a n g u a g e .(\gamma)^{\prime}(x, \varnothing)\right]\right)$

Tell:

Tellan: $x$ (Nom-A)

da ungewiderunge de comon swa we beforan tealdon

'The bad weather came as we said'

Tell and tellan are causative accomplishments where the three external variables $\mathrm{x}, \mathrm{y}, \mathrm{z}$ can be syntactically realised (1). There are some differences in the syntax-semantics linking of these verbs, particularly in the assignment of the macrorole Undergoer. Tellan always assigns to the variable $\mathrm{z}$ the macrorole Undergoer, whereas tell assigns this macrorole to the variable y, except for the case of Dative alternation, where both the variable y (Ellen told Helen a story) or the variable z (Ellen told a story to Helen) can be Undergoer. That is the reason why tell does not allow the assignment of the preposition to to the variable $y$, since this preposition can only be assigned to a nonmacrorole argument (Van Valin and LaPolla 1997: 377). The same occurs in (3).

Causative accomplishments can also be found where only the external variables $\mathrm{x}$ and $\mathrm{z}$ (2) or $\mathrm{x}$ and $\mathrm{y}$ (3) have a syntactic realisation. According to the Default Macrorole Assignment Principles and the Case assignment rules, the variable $x$ takes the macrorole Actor and in OE Nominative case. In (2) the variable $\mathrm{z}$ takes the macrorole Undergoer and in OE Accusative case, except when this variable is realised by a clausal subordination, whereas in (3) it is the variable $y$ which takes the macrorole Undergoer and in OE Accusative case.

Applying the Lexical Template Modeling Process, from the causative accomplishment template activities can be derived with one of the arguments being realised by a prepositional phrase, or with $\mathrm{x}$ as Actor and $\mathrm{y}$ as a nonmacrorole direct core argument taking in OE Dative case $(4,5)$, or in the case of tellan, with only $\mathrm{x}$ having a syntactic realisation, being the Actor and taking Nominative case (6).

As the following two sections show, the syntactic behaviour of these lexemes will provide information about the degree of transitivity that they present as well as about the semantic coverage of these lexemes within their respective domains. 


\section{DEGREE OF PROTOTYPICALITY OF TRANSITIVE CONSTRUCTIONS}

Following Givón (1984) and Taylor (1995), the syntactic alternations above will be arranged according to the degree of prototypicality of the transitive construction, that is, from more central members to more marginal ones. Taylor (1995: 177), dealing with syntactic constructions as prototype categories, argues the following:

Possibility of occurrence in a construction is more a matter of gradience, some items being readily available, others being totally excluded, with, in between, a range of items whose use is dubious or sporadic. As a consequence, constructions (...) also need to be regarded as prototype categories, with some instantiations counting as better examples of the construction than others.

Accordingly, the syntactic alternations in sections 3.1 y 3.2 have been arranged as follows:

\begin{tabular}{|c|c|c|c|c|}
\hline Syntactic alternations & SAY & SECGAN & TELL & TELLAN \\
\hline $\mathrm{x}, \mathrm{z}$ & $\mathrm{x}$ & $\mathrm{x}$ & $\mathrm{x}$ & $\mathrm{x}$ \\
\hline $\begin{array}{c}\mathrm{x}, \mathrm{z} \\
{[\text { Clausal subordination] }}\end{array}$ & $\mathrm{x}$ & $\mathrm{x}$ & $\mathrm{x}$ & $\mathrm{x}$ \\
\hline $\begin{array}{c}\mathrm{x}, \mathrm{z} \\
{[\text { Core coordination] }}\end{array}$ & $\mathrm{x}$ & & & \\
\hline $\mathrm{x}, \mathrm{z}$ & $\mathrm{x}$ & $\mathrm{x}$ & & \\
\hline [Sentential coordination] & $\mathrm{x}$ & $\mathrm{x}$ & $\mathrm{x}$ & $\mathrm{x}$ \\
\hline $\mathrm{x}, \mathrm{y}, \mathrm{z}$ & $\mathrm{x}$ & $\mathrm{x}$ & $\mathrm{x}$ & $\mathrm{x}$ \\
\hline $\begin{array}{c}\mathrm{x}, \mathrm{y}, \mathrm{z} \\
{[\text { Clausal subordination] }}\end{array}$ & $\mathrm{x}$ & & $\mathrm{x}$ & \\
\hline $\begin{array}{c}\mathrm{x}, \mathrm{y}, \mathrm{z} \\
{[\text { Core coordination] }}\end{array}$ & $\mathrm{x}$ & $\mathrm{x}$ & $\mathrm{x}$ & \\
\hline $\begin{array}{c}\mathrm{x}, \mathrm{y}, \mathrm{z} \\
{[\text { Sentential coordination] }}\end{array}$ & & & $\mathrm{x}$ & $\mathrm{x}$ \\
\hline $\mathrm{x}, \mathrm{y}$ [y-U] & & & \\
\hline
\end{tabular}

\begin{tabular}{|c|c|c|c|c|}
\hline $\mathrm{x}, \mathrm{y},[$ about $+\mathrm{z}]$ & & $\mathrm{x}$ & $\mathrm{x}$ & $\mathrm{x}$ \\
\hline $\mathrm{x},[$ about $+\mathrm{y}]$ & & $\mathrm{x}$ & & $\mathrm{x}$ \\
\hline $\mathrm{x}, \mathrm{y}$ & & $\mathrm{x}$ & & \\
\hline $\mathrm{x}$ & & $\mathrm{x}$ & & $\mathrm{x}$ \\
\hline
\end{tabular}

Table 2. Degree of prototypicality of the transitive constructions of say/secgan and tell/tellan 
Firstly, this table shows that the most prototypical example of the transitive construction is that where there are two arguments with a specific reference $(\mathrm{x}, \mathrm{z})$. The following alternations with the variable $\mathrm{z}$ being syntactically realised by a clausal subordination, a core coordination or a sentential coordination would illustrate some kind of deviation from the prototypical construction.

The different realisations of the variable $\mathrm{z}$ have also been arranged following Van Valin and LaPolla (1997)'s proposal about the degree of integration of arguments within the main clause. According to these authors, subordinate arguments present a stronger link with the main core than coordinate arguments.

Secondly, more marginal members of this construction are the alternations with three arguments $(\mathrm{x}, \mathrm{y}, \mathrm{z})$ where the recipient $(\mathrm{y})$ can sometimes function as Undergoer, as the Dative alternation with tell showed. With the alternation $\mathrm{x}, \mathrm{y}[\mathrm{U}]$ without mention of the patient $(\mathrm{z})$ "we are approaching the outer limits of the transitive construction" (Taylor 1995: 213).

And thirdly, the last four cases designating activities are separated from the previous ones, because they would correspond to the less-prototypical transitive construction (cf. Martín Arista and Caballero González: forthcoming). Therefore, according to the degree of prototypicality of the transitive construction, say and tell can be said to be more transitive than secgan and tellan.

However, the situation would be rather different if we compared speak/sprecan, since as the following alternations show sprecan presents more transitive alternations than speak, or what is the same, speak would be more intransitive than sprecan:

(1) do' $\left(x,\left[\right.\right.$ express. $(\alpha)$.to. $(\beta)$.in.language. $\left.\left.(\gamma)^{\prime}(x, y)\right]\right) \&$ [BECOME aware.of' $(y, z)]$, where $y=\beta, z=\alpha$

\section{Speak:}

Sprecan: $x$ (Nom-A), z (Acc-U), y (oblique core arg)

he wile symle to his nehstan sprecan da word

'He will ever tell stories to his neighbour'

(2) do' $\left(x,\left[\right.\right.$ express. $\left.\left.(\alpha) . t o .(\beta) . i n . l a n g u a g e .(\gamma)^{\prime}(x, \varnothing)\right]\right) \&$ [BECOME aware.of' $(\varnothing, \mathrm{z})]$, where $\varnothing=\beta, \mathrm{z}=\alpha$

2.1. Speak: $x(A), z(U)$

I spoke these words.

Sprecan: $x$ (Nom-A), z (Acc-U)

Ic (...) ne moeg word sprecan 'I may not say a word' 
2.2.Speak: *Ellen talked (to Helen) that the party was tomorrow.

Sprecan: $\mathrm{x}$ (Nom-A), z [Clausal subordination-U]

Hie sprocon, doet hit betere wore (B\&T) 'They said that it was better'

\subsection{Speak:}

Sprecan: $x$ (Nom-A), z [Sentential coordination]

Hi sare sprecaд: Hwa gesyhд usic? (B\&T)

'They speak with affliction: "Who knows us?"

(3) do' $\left(x\right.$, [express. $(\alpha)$.to. $(\beta)$.in.language. $\left.\left.(\gamma)^{\prime}(x, y)\right]\right) \wedge[$ about' $(z)]$, where $\alpha=$ [about'(z)]

Speak: She spoke to Helen about him.

Sprecan:

(4) do' $\left(x,\left[\right.\right.$ express. $\left.\left.(\alpha) . t o .(\beta) . i n . l a n g u a g e .(\gamma)^{\prime}(x, \varnothing)\right]\right) \wedge[$ about' $(y)]$, where $\partial=[$ about'(y)]

Speak: $x(A)$, [about'(y)]

She spoke about him.

Sprecan: $x$ (Nom-A), [be/ymbe/embe + Dat PP]

fordan de hi gehyrdon hine be dam cyrclicum madmum sprecan

'Because they heard him talk about ecclesiastical treasures'

(5) do' $\left(x\right.$, [express. $(\alpha)$. to. $(\beta)$. in.language. $\left.\left.(\gamma)^{\prime}(x, y)\right]\right)$

Speak: $\mathrm{x}(\mathrm{A}), \mathrm{y}$ (oblique core $\arg$ )

Ellen spoke to Helen.

Sprecan: $\mathrm{x}$ (Nom-A), y (oblique core arg)

ne mihte he him to sprecan 'He might not talk to him'

(6) do' $\left(x\right.$, [express. $(\alpha)$. to. $(\beta)$.in.language. $\left.\left.(\gamma)^{\prime}(x, \varnothing)\right]\right)$

Speak: $x(A)$

Ellen spoke.

Sprecan: $x$ (Nom-A)

swilce hi wislice sprecan

'Such as they wisely speak' 


\begin{tabular}{|c|c|c|}
\hline Syntactic alternations & SPEAK & SPRECAN \\
\hline $\mathrm{x}, \mathrm{z}$ & $\mathrm{x}$ & $\mathrm{x}$ \\
\hline $\begin{array}{c}\mathrm{x}, \mathrm{z} \\
{[\text { Clausal subordination] }}\end{array}$ & & $\mathrm{x}$ \\
\hline $\begin{array}{c}\mathrm{x}, \mathrm{z} \\
{[\text { Sentential coordination] }}\end{array}$ & & $\mathrm{x}$ \\
\hline $\mathrm{x}, \mathrm{y}, \mathrm{z}$ & & \\
\hline \hline $\mathrm{x}, \mathrm{y},[\mathrm{about}+\mathrm{z}]$ & $\mathrm{x}$ & $\mathrm{x}$ \\
\hline $\mathrm{x},[\mathrm{about}+\mathrm{y}]$ & $\mathrm{x}$ & $\mathrm{x}$ \\
\hline $\mathrm{x}, \mathrm{y}$ & $\mathrm{x}$ & $\mathrm{x}$ \\
\hline $\mathrm{x}$ & $\mathrm{x}$ & $\mathrm{x}$ \\
\hline
\end{tabular}

Table 3. Degree of prototypicality of the transitive constructions of speak/sprecan

\section{THE LEXICAL ICONICITY PRINCIPLE (BETA READING)}

The Lexical Iconicity Principle (Beta Reading), developed by Cortés Rodríguez and Mairal Usón (forthcoming), stems from the Lexical Iconicity Principle proposed by Faber and Mairal Usón (1997a: 138). This principle states that the greater the syntactic coverage of a lexical unit, the higher its position in the semantic hierarchy within a given subdomain. Thus, taking into account the syntactic information included in Table 2, secgan and tellan present a greater semantic coverage than their PDE counterparts, that is, the latter have lost semantic space within the domain of speech with respect to the OE verbs.

\section{CONCLUDING REMARKS}

Within the FLM framework for lexical analysis the notion of lexical template has been integrated as a way of representing the interaction between syntax and semantics. FLM templates enrich the logical structures as developed by Van Valin and LaPolla (1997) with a semantic decomposition which captures generalisations within verbal classes, reducing the information to be included in the lexical entries.

Therefore, each domain is characterised by a lexical template, from which the syntactic behaviour and alternations of the lexemes that integrate them will be derived. In the case of say/secgan and tell/tellan, they share a template 
containing an accomplishment or causative accomplishment from where different syntactic alternations will be derived depending on the linking rules for each language.

Finally, according to the degree of prototypicality of the transitive construction, the syntactic alternations of these lexemes show the evolution of the PDE verbs say and tell in relation to their OE counterparts, with the former becoming more transitive than the latter. This evolution, on the other hand, has also meant a restriction in the semantic coverage of the PDE verbs within the domain of speech.

\section{REFERENCES}

Bosworth, J. and T. N. Toller 1973 (1898). An Anglo-Saxon Dictionary. Oxford: O.U.P.

Cortés Rodríguez, F. and R. Mairal Usón (forthcoming). "A Preliminary Design for a Syntactic Dictionary of Old English on Semantic Principles". A Changing World of Words. Ed. J. Díaz Vera. Amsterdam: Rodopi. 3-46.

Cortés Rodríguez, F. and M. J. Pérez Quintero 2001. "Finding Relief for FG Lexical Representations: A Syntactic-Semantic Description of Old English Verbs of 'Healing'". Challenges and Developments in Functional Grammar. Ed. M.J. Pérez Quintero. Revista Canaria de Estudios Ingleses 42: 79-101.

Coseriu, E. 1978. Gramática, Semántica, Universales. Madrid: Gredos.

Coseriu, E. 1981 (1977). Principios de Semántica Estructural. Madrid: Gredos.

Dik, S. C.1978. Stepwise Lexical Decomposition. Lisse: de Ridder.

Faber, P. and R. Mairal Usón 1994. "Methodological Underpinnings for the Construction of a Functional Lexicological Model". Miscelanea: A Journal of English and American Studies 15: 193-217.

Faber, P. and R. Mairal Usón 1997a. "The Paradigmatic and Syntagmatic Structure of the Lexical Field of EXISTENCE in the Elaboration of a Semantic Macronet". Studies in Language 21 (1): 129-167.

Faber, P. and R. Mairal Usón 1997b. "The Paradigmatic and Syntagmatic Structure of the Lexical Field of Feeling". Cuadernos de Investigación Filológica 23-24: 35-60.

Faber, P. and R. Mairal Usón 1999. Constructing a Lexicon of English Verbs. Berlin/New York: Mouton de Gruyter.

Faber, P. and R. Mairal Usón 2000. "Reconsidering Lexical Representations in Functional Grammar". Paper presented at the $9^{\text {th }}$ International Conference on Functional Grammar. Madrid.

Givón, T. 1984. Syntax. A Functional Typological Introduction. Vols. I/II. 
Amsterdam/Philadelphia: John Benjamins.

Healey, A. di P., ed. The Dictionary of Old English Corpus. Web-site 0-472-00277-5.

Levin, B. 1993. English Verb Classes and Alternations. Chicago/London: The University of Chicago Press.

Mairal Usón, R. 1993. Complementation Patterns of Cognitive, Physical Perception and Speech Act Verbs in the English Language. A Functional-Cognitive Approach. Dissertation. University of Zaragoza.

Mairal Usón, R. and R. D. Van Valin 2001. "What Role and Reference Grammar Can Do for Functional Grammar". Challenges and Developments in Functional Grammar. Ed. M.J. Pérez Quintero. Revista Canaria de Estudios Ingleses 42: 137-166.

Martín Arista, J. and L. Caballero González. "Arguments or Macroroles? Two Functional Approaches to Old English Quirky Case”. Journal of English Studies, vol. 3 (2001-2): 131-148

Martín Mingorance, L. 1998. El Modelo Lexemático-Funcional. El Legado Lingüístico de Leocadio Martín Mingorance. Ed. A. Marín Rubiales. Granada: Servicio de Publicaciones.

Taylor, J. R. 1995 (1989). Linguistic Categorization. Oxford: Clarendon Press.

Toller T. N. and A. Campbell 1972 (1921). An Anglo-Saxon Dictionary. Supplement. Oxford: O.U.P.

Van Valin, R. D. and R. LaPolla 1997. Syntax: Structure, Meaning and Function. Cambridge: C.U.P. 